\title{
Giant solitary fibrous tumour of the liver
}

\section{Türkan Terkivatan ${ }^{1}$, Mike Kliffen ${ }^{2}$, Johannes HW de Wilt ${ }^{1}$, Albertus N van Geel $^{1}$, Alexander MM Eggermont ${ }^{1}$ and Cornelis Verhoef ${ }^{* 1}$}

\author{
Address: ${ }^{1}$ Department of Surgical Oncology, Erasmus University Medical Center, Daniel den Hoed Cancer Center, Rotterdam, The Netherlands \\ and ${ }^{2}$ Department of Pathology, Erasmus University Medical Center, Daniel den Hoed Cancer Center, Rotterdam, The Netherlands \\ Email: Türkan Terkivatan - t.terkivatan@erasmusmc.nl; Mike Kliffen - m.kliffen@erasmusmc.nl; Johannes HW de \\ Wilt - j.h.w.dewilt@erasmusmc.nl; Albertus N van Geel - a.n.vangeel@erasmusmc.nl; \\ Alexander MM Eggermont - a.m.m.eggermont@erasmusmc.nl; Cornelis Verhoef* - c.verhoef@erasmusmc.nl \\ * Corresponding author \\ Published: 21 November 2006 \\ World Journal of Surgical Oncology 2006, 4:8I doi:10.1 |86/1477-78|9-4-8I \\ This article is available from: http://www.wjso.com/content/4/l/8I \\ (c) 2006 Terkivatan et al; licensee BioMed Central Ltd. \\ This is an Open Access article distributed under the terms of the Creative Commons Attribution License (http://creativecommons.org/licenses/by/2.0), \\ which permits unrestricted use, distribution, and reproduction in any medium, provided the original work is properly cited.
}

\begin{abstract}
Background: Solitary fibrous tumour (SFT) is an uncommon mesenchymal neoplasm that most frequently affects the pleura, although it has been reported with increasing frequency in various other sites such as in the peritoneum, pericardium and in non-serosal sites such as lung parenchyma, upper respiratory tract, orbit, thyroid, parotid gland, or thymus. Liver parenchyma is rarely affected. Clinically, SFTs cause symptoms after having reached a certain size or when vital structures are involved. In recent years, SFTs are more often identified and distinguished from other tumours with a similar appearance due to the availability of characteristic immunohistochemical markers.

Case presentation: In this manuscript we report the case of a large tumour of the liver, which was histologically diagnosed as a SFT, and showed involvement of a single hepatic segment. Because of the patient's presentation and clinical course, it may represent a radiation-induced lesion.

Conclusion: When a SFT has been diagnosed, surgery is the treatment of choice. The small number of patients with a SFT of the liver and its unknown natural behaviour creates the need to a careful registration and follow-up of all identified cases
\end{abstract}

\section{Background}

Solitary fibrous tumour (SFT) is an uncommon mesenchymal neoplasm that most frequently affects the pleura $[1,2]$, although it has been reported with increasing frequency in various other sites such as in the peritoneum [3], in the pericardium [4] and in non-serosal sites such as lung parenchyma [5], upper respiratory tract [6], orbit [7], thyroid [8], parotid gland [9], or thymus [10]. Liver parenchyma is rarely affected [11]. Clinically, SFTs cause symptoms after having reached a certain size or when vital structures are involved. In recent years, SFTs are more often identified and distinguished from other tumours with a similar appearance due to the availability of immunohistochemical markers $[12,13]$.

In this manuscript we report the case of a large tumour of the liver, which was histologically diagnosed as a SFT, and showed involvement of a single hepatic segment. Because of the patient's presentation and clinical course, it may represent a radiation-induced lesion. 


\section{Case presentation}

A 74-year-old man was referred to our department with complains of gastric fullness, frequent episodes of postprandial nausea, and weight loss over the previous 3 months. Medical history revealed a high-grade mucosaassociated lymphoid tissue (MALT) lymphoma of the stomach in 1996. The lymphoma was staged as IE according to the Ann Arbor staging system, and showed complete response after chemotherapy followed by radiation therapy (60 Gy) of the local nodal regions. On physical examination, a large mass was palpated in the epigastrium that filled the entire right upper quadrant of the abdomen. Routine laboratory investigations, including blood glucose levels, and serum levels of tumour markers (alphafetoprotein [AFP], carcinoembryonic antigen [CEA], and carbohydrate antigen [Ca19-9]) were within normal limits. Computed tomography (CT) of the abdomen demonstrated a large, heterogeneous mass in the left hepatic lobe, measuring $24 \mathrm{~cm}$ in largest diameter, with necrosis and calcification (Figure 1). There were no signs of recurrence of high grade MALT lymphoma. Liver biopsy showed spindle-cell elements with cellular atypia suggesting a sarcoma. Laparotomy was performed and revealed a large tumour, which only involved segment IV of the liver, and a left lobectomy was performed. Postoperative course was uneventful. After 12 months of follow-up the patient had no signs of local recurrence or distant metastases.

\section{Pathologic examination}

Gross examination showed a large tumour measuring 24 $\times 21 \times 15 \mathrm{~cm}$ that weighed $2950 \mathrm{~g}$ (Figure 2). Macroscopically, the tumour was located in the liver parenchyma and not in relation to serosal surface. The lesion was well encapsulated, and contained a number of central necrotic and scarred areas with radiating bands of fibrous tissue. Microscopically, the tumour was composed of neoplastic spindle cells, with uniform, elongated nuclei, separated by abundant thick bands of collagen (Figure $3 a$, and $3 b$ ). A few highly cellular areas with high mitotic rate of 10 13 mitosis/10 HPF were detected. In the higher cellular areas, cells were close together with limited amounts of collagen (Figure 3c). The organization of the tumour cells was different in several areas, varying from small bundles of spindle cells arranged haphazardly, arranged in some groups with nuclear pallisading or in a storiform pattern. Cells were separated by an abundant reticulin network, which appeared in a random pattern. An abundant thin walled vascular network was present with some heamangiopericyoma-like vascular spaces (Figure 3a). Immunohistochemistry revealed strong expression of CD34, CD99, BCL2 and vimentin in virtually all tumour cells (Figure 3d,3e, and 3f). No immunoreactivity was shown with pankeratin, keratin 8/18, epithelial membrane antigen, smooth-muscle actin, desmin, S100, Factor VIII, CD 31 and CD117. Epidermal growth factor receptor (EGFR)

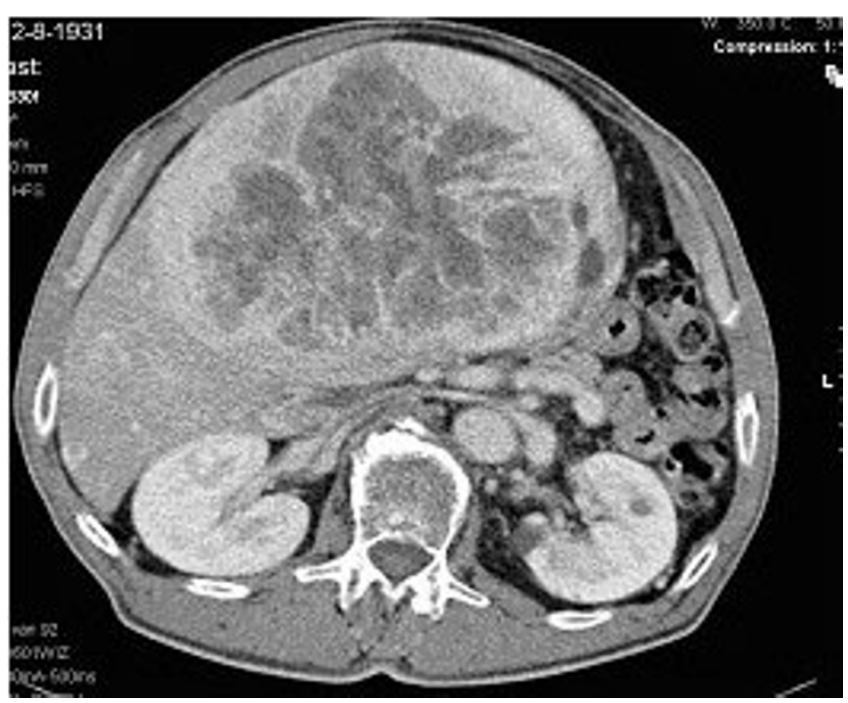

Figure I

CT-scan of the liver preoperative.

(100\%) and progesterone receptor (10\%-20\%) were positive. Oestrogen receptor (ER) and Her-2 neu were negative.

\section{Discussion}

The possible relationship between irradiation and neoplasia is well known. Radiation-induced soft tissue tumours are uncommon and mostly high-grade lesions, such as angiosarcoma after irradiation of the breast $[14,15]$. SFT of the liver has not been described in the context of radiation, but it was reported that radiation of the liver may

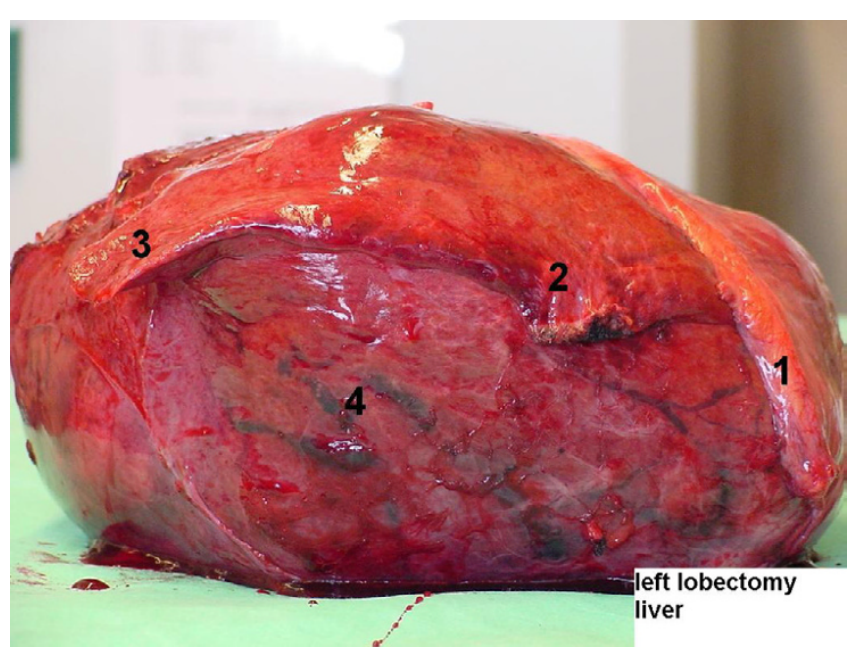

Figure 2

Left Lobectomy specimen. Large tumour situated in segment IV, atrophy of segments II and III. I: falciform ligament, 2: segment II, 3: segment III, 4: segment IV (tumour). 

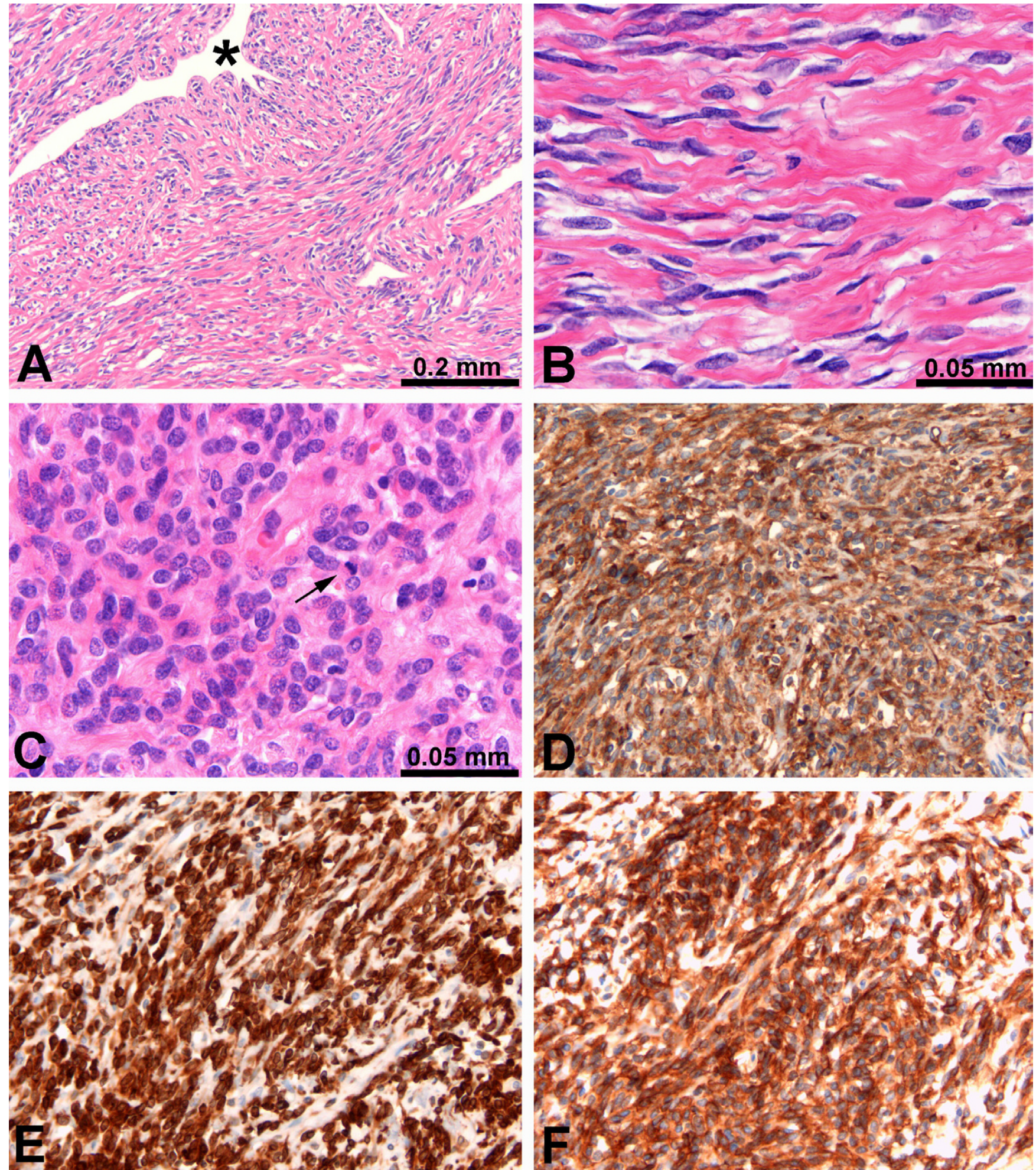

Figure 3

Light microscopy. A Characteristic picture of the tumour showing spindle cells with surrounding hyalinized collagen bundles, and haemangiopericytoma-like vascular space $(*)$. B Higher magnification of spindle cell area with intermixed collagen. C Higher magnification of cellular area with little collagen and increased amount of mitoses (arrow). D, E, and F Immunohistochemical staining for CD34, BCL-2, and CD99, respectively. 
cause an inflammatory reaction and fibrosis which may cause radiation-induced liver disease [16]. In the presented case; the tumour was developed in the documented field of irradiation, the tumour was detected 9 years after exposure and chronic lymphedema was not present in the liver. Our patient satisfies all the three criteria to consider a tumour to be irradiation related [17]. Since the mid-to-late 1990 s positive immunohistochemical staining for CD34 and vimentin, along with a haemangiopericytoma-like appearance, became the hallmark of SFTs $[12,13]$. Nowadays, the monoclonal antibody CD34 has received a wide consensus as a diagnostic marker for SFT, and an increasing number are reported in the literature [11]. Although immunoreactivity with CD34 is believed to be highly characteristic of SFTs, and a positive CD34 staining is required for diagnosis, the immunohistologic staining pattern is not entirely specific [18]. Other entities, such as angiosarcoma and gastrointestinal stromal tumour, also express CD34 and vimentin epitopes $[19,20]$. Therefore, other histomorphological and immunohistochemical characteristics remain evenly important. In the present case, CD117 negativity, CD31 negativity, Factor VIII negativity combined with the histomorphology, excluded gastrointestinal stromal tumour and angiosarcoma. The strong expression of CD99 and BCL2 in the tumour cells further supports the diagnosis of SFT, but as stand-alones these markers would not be sufficient.

Histologically, the alternating hypercellular and hypocellular areas and a hemangiopericytoma-like vascular pattern with abundant branching of thin-walled vessels dissecting through the tumour, are typical findings in benign and malignant SFT of the liver $[21,22]$. The focal presence of intense hypercellularity accompanied by increased nuclear atypia and an elevated mitotic rate are criteria for malignant change, as is necrosis. There is also some evidence that the rate of mitosis as well as the size of the tumour might well be possible predictors of local recurrence and metastatic disease $[21,23]$. These malignant elements may not be detected on a needle core biopsy due to the hazard of sampling error, and a histopathological examination of the resected specimen is needed to predict clinical course.

When a SFT has been diagnosed, surgery is the treatment of choice. Although not a primarily malignant disease, it seems to be of importance to achieve tumour-free margins in order to prevent local recurrence or distant metastasis $[21,23]$. Due to the infrequent prevalence of SFT, malignant potential and recurrence rate can not be determined exactly. According to the literature, intra-thoracic SFTs show a local recurrence and distant metastatic rate of up to $15 \%$, while extra-thoracic tumours may demonstrate malignant behaviour in approximately $6 \%$ [11].

\section{Conclusion}

When a SFT has been diagnosed, surgery is the treatment of choice. The small number of patients with a SFT of the liver and its unknown natural behaviour creates the need to a careful registration and follow-up of all identified cases. Because of the patient's presentation and clinical course in our case, it may represent a radiation-induced lesion.

\section{Competing interests}

The author(s) declare that they have no competing interests.

\section{Authors' contributions}

CV and JHW carried out the surgical procedure and contributed to the design of the study. TT and $\mathrm{CV}$ gathered the data from the literature search and made the first draft of the manuscript. MK performed the histological analysis of the surgical specimen and provided histological sections as figures for the manuscript. ANG, AMME and JHW revised and finally approved the manuscript for been published. All authors approved the final manuscript.

\section{Acknowledgements}

Written consent of the patient was obtained for publication of this case report.

\section{References}

I. Lee SC, Tzao C, Ou SM, Hsu HH, Yu CP, Cheng YL: Solitary fibrous tumors of the pleura: clinical, radiological, surgical and pathological evaluation. Eur / Surg Oncol 2005, 31:84-87.

2. Sung SH, Chang JW, Kim J, Lee KS, Han J, Park SI: Solitary fibrous tumors of the pleura: surgical outcome and clinical course. Ann Thorac Surg 2005, 79:303-307.

3. Lee JR, Hancock SM, Martindale RG: Solitary fibrous tumors arising in abdominal wall hernia sacs. Am Surg 200I, 67:577-58I.

4. Val-Bernal JF, Figols J, Gomez-Roman JJ: Incidental localized (solitary) epithelial mesothelioma of the pericardium: case report and literature review. Cardiovasc Pathol 2002, I I: I8I-I85.

5. Patsios D, Hwang DM, Chung TB: Intraparenchymal solitary fibrous tumor of the lung: an uncommon cause of a pulmonary nodule. J Thorac Imaging 2006, 21 : 50-53.

6. Alobid I, Alos L, Blanch JL, Benitez P, Bernal-Sprekelsen M, Mullol J: Solitary fibrous tumour of the nasal cavity and paranasal sinuses. Acta Otolaryngol 2003, I 23:7I-74.

7. Bernardini FP, de Conciliis C, Schneider S, Kersten RC, Kulwin DR: Solitary fibrous tumor of the orbit: is it rare? Report of a case series and review of the literature. Ophthalmology 2003, I 1 0:1442-1448.

8. Rodriguez I, Ayala E, Caballero C, De Miguel C, Matias-Guiu X, Cubilla AL, Rosai J: Solitary fibrous tumor of the thyroid gland: report of seven cases. Am J Surg Pathol 200I, 25: I 424-I 428.

9. Gerhard R, Fregnani ER, Falzoni R, Siqueira SA, Vargas PA: Cytologic features of solitary fibrous tumor of the parotid gland. A case report. Acta Cytol 2004, 48:402-406.

10. Tangthangtham A, Chonmaitri I, Subhannachart P, Kasemsarn C: Solitary fibrous tumor arising from hyperplastic thymus. J Med Assoc Thai 1998, 81:708-7II.

II. Neeff H, Obermaier R, Technau-Ihling K, Werner M, Kurtz C, Imdahl A, Hopt UT: Solitary fibrous tumour of the liver: case report and review of the literature. Langenbecks Arch Surg 2004, 389:293-298.

12. Apple SK, Nieberg RK, Hirschowitz SL: Fine needle aspiration biopsy of solitary fibrous tumor of the pleura. A report of two cases with a discussion of diagnostic pitfalls. Acta Cytol 1997, 4 I: I528-1533. 
13. Moran CA, Ishak KG, Goodman ZD: Solitary fibrous tumor of the liver: a clinicopathologic and immunohistochemical study of nine cases. Ann Diagn Pathol 1998, 2:19-24.

14. Vorburger SA, Xing Y, Hunt KK, Lakin GE, Benjamin RS, Feig BW, Pisters PW, Ballo MT, Chen L, Trent J III, Burgess M, Patel S, Pollock RE, Cormier JN: Angiosarcoma of the breast. Cancer 2005, 104:2682-2688.

15. West JG, Qureshi A, West JE, Chacon M, Sutherland ML, Haghighi B, Harrison J: Risk of angiosarcoma following breast conservation: a clinical alert. Breast J 2005, I I: I I5- I 23.

16. Dawson LA, Ten Haken RK, Lawrence TS: Partial irradiation of the liver. Semin Radiat Oncol 200 I, I I:240-246.

17. Patel SR: Radiation-induced sarcoma. Curr Treat Options Oncol 2000, I:258-26I.

18. Chan JK: Solitary fibrous tumour--everywhere, and a diagnosis in vogue. Histopathology 1997, 31:568-576.

19. Favia G, Lo ML, Serpico R, Maiorano E: Angiosarcoma of the head and neck with intra-oral presentation. A clinico-pathological study of four cases. Oral Oncol 2002, 38:757-762.

20. Wang L, Vargas H, French SW: Cellular origin of gastrointestinal stromal tumors: a study of $\mathbf{2 7}$ cases. Arch Pathol Lab Med 2000, 124:147|- I475.

21. Gold JS, Antonescu CR, Hajdu C, Ferrone CR, Hussain M, Lewis J], Brennan MF, Coit DG: Clinicopathologic correlates of solitary fibrous tumors. Cancer 2002, 94:1057-1068.

22. Levine TS, Rose DS: Solitary fibrous tumour of the liver. Histopathology 1997, 30:396-397.

23. Yilmaz S, Kirimlioglu V, Ertas E, Hilmioglu F, Yildirim B, Katz D, Mizrak B: Giant solitary fibrous tumor of the liver with metastasis to the skeletal system successfully treated with trisegmentectomy. Dig Dis Sci 2000, 45: 168-174.

Publish with Bio Med Central and every scientist can read your work free of charge

"BioMed Central will be the most significant development for disseminating the results of biomedical research in our lifetime. "

Sir Paul Nurse, Cancer Research UK

Your research papers will be:

- available free of charge to the entire biomedical community

- peer reviewed and published immediately upon acceptance

- cited in PubMed and archived on PubMed Central

- yours - you keep the copyright

Submit your manuscript here:

http://www.biomedcentral.com/info/publishing_adv.asp
BioMedcentral 